\title{
Correction: Knockdown of clusterin sensitizes pancreatic cancer cells to gemcitabine chemotherapy by ERK1/2 inactivation
}

\author{
Yong Tang ${ }^{1 \dagger}$, Fenghua Liu ${ }^{1 \dagger}$, Chunning Zheng ${ }^{2}$, Shaochuan Sun ${ }^{2 *}$ and Yingsheng Jiang ${ }^{2}$
}

\section{Correction}

After the publication of this work [1], we noticed that we had incorrectly used the term 'OGX-011'. All instances of OGX-011 in the manuscript should be changed to 'ASO-CLU', apart from the last paragraph in the Introduction section which should remain as published.

We also noticed in the first sentence of the second paragraph of the Materials and methods section we mistakenly stated that OGX-011 (ASO-CLU) was purchased from OncoGenex Technologies. As ASO-CLU is currently in the clinical testing phase, it is not available for sale from OncoGenex Technologies. The corrected sentence should read:

ASO-CLU was acquired from OncoGenex Technologies.

We apologise to the readers and OncoGenex Technologies for this oversight and any negative effects that may have resulted from it.

\footnotetext{
Author details

'Pancreatic Cancer, Key Laboratory of Cancer Prevention and Therapy, Tianjin Medical University Cancer Institute and Hospital, Tianjin, China. ${ }^{2}$ Department of general surgery, the affiliated hospital of Jinan central hospital, Shandong university, No105, Jiefang Road, District Lixia, Jinan 250013, R. P. China.
}

Received: 27 February 2013 Accepted: 27 February 2013

Published: 2 July 2013

\section{References}

1. Tang Y, Liu F, Zheng C, Sun S, Jiang Y: Knockdown of clusterin sensitizes pancreatic cancer cells to gemcitabine chemotherapy by ERK $1 / 2$ inactivation. J Exp Clin Cancer Res 2012, 31:73.

doi:10.1186/1756-9966-32-42

Cite this article as: Tang et al:: Correction: Knockdown of clusterin sensitizes pancreatic cancer cells to gemcitabine chemotherapy by ERK1/2 inactivation. Journal of Experimental \& Clinical Cancer Research 2013 32:42

\footnotetext{
* Correspondence: sunschuansd@126.com

${ }^{\dagger}$ Equal contributors

${ }^{2}$ Department of general surgery, the affiliated hospital of Jinan central hospital, Shandong university, No105, Jiefang Road, District Lixia, Jinan 250013, R. P. China
}

\section{Submit your next manuscript to BioMed Central and take full advantage of:}

- Convenient online submission

- Thorough peer review

- No space constraints or color figure charges

- Immediate publication on acceptance

- Inclusion in PubMed, CAS, Scopus and Google Scholar

- Research which is freely available for redistribution

Submit your manuscript at

www.biomedcentral.com/submit
() Biomed Central (c) 2013 Tang et al.; licensee BioMed Central Ltd. This is an Open Access article distributed under the terms of the Creative Commons Attribution License (http://creativecommons.org/licenses/by/2.0), which permits unrestricted use, distribution, and reproduction in any medium, provided the original work is properly cited. 